\title{
THE PATTERN OF CHRIST'S SUFFERINGS: COLOSSIANS 1:24 AND PHILIPPIANS 3:10-11
}

\section{Andrew Perriman}

There are two passages in the corpus of Paul's letters where he speaks explicitly and personally about his sharing in the sufferings of Christ, viz. Colossians 1:24 and Philippians 3:10-11. It is the suggestion of this essay that they have not been properly understood. In each case the difficulties for commentators have focused on an apparent and particular anomaly. How can Paul speak in Colossians 1:24 of making up the deficit of Christ's afflictions? And why, in Philippians 3:11, does his expectation of coming to the resurrection of the dead suddenly become so uncertain? The purpose of the present exegetical investigation is to show how these anomalies might be resolved and how that resolution would then point towards a more distinctive attitude on Paul's part towards his own suffering and death than most commentators have allowed for. ${ }^{1}$

\section{Colossians 1:24}

A recurrent peculiarity of the exegetical history of Colossians 1:24 is the displacement of the words 'in my flesh'. To cite one of the more recent examples, P.T. O'Brien shifts the phrase to the beginning. Whereas the Greek reads, kai

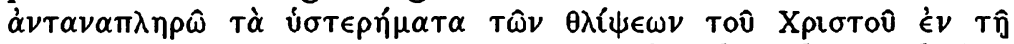

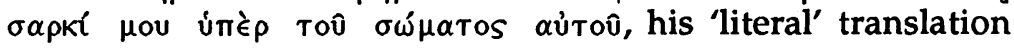
reads 'And in my flesh I complete what is lacking in Christ's afflictions for the sake of his body. ...2 This tendency to asso-

\footnotetext{
${ }^{1}$ By taking the Colossians passage as the starting-point for the analysis the grey spectre of the authenticity issue is for some immediately conjured up. The weakest justification for such an approach is that Colossians at least reflects Pauline thought. But it is my view, on the one hand, that Colossians 1:24, when properly understood, provides perhaps the best insight into Paul's argument in Philippians 3:7-14, and on the other, that the continuity of thought between the two passages should in turn be taken into account in discussions of the authorship of Colossians.

2P.T. O'Brien, Colossians, Philemon (Waco, Word Books 1982) 77; cf. J.A.T. Robinson, The Body (SCM 1952) 70; E. Best, One Body in Christ (SPCK 1955)
} 
ciate the phrase with $\dot{\alpha} \nu \tau \alpha \nu \alpha \pi \lambda \eta \rho \hat{\omega}$ points to one of the main reasons why commentators have taken a particular interpretation of this verse, supposing that the distinction Paul makes here is between those 'afflictions of Christ' that have occurred or will occur outside his own person and those which he proposes to undergo in his own flesh. The position of $\dot{\epsilon} v \tau \hat{\eta} \sigma \alpha \rho \hat{i}^{\prime}$ rou however, suggests that a different interpretation is more probable, according to which the distinction educed by $\dot{\alpha} \nu \tau \alpha \nu \alpha \pi \lambda \eta \rho \hat{\omega}$ falls entirely within Paul's experience, between those 'afflictions of Christ' which he has already suffered and those which he expects or even hopes to suffer. In this way $\dot{\epsilon} v$ $\tau \hat{\eta} \sigma \alpha \rho \kappa^{\prime}$ uov directly and naturally qualifies the preceding expression. ${ }^{3}$ It is his own experience of the afflictions of Christ that is incomplete. C.M. Proudfoot's argument that the absence of an article before the phrase prevents us from taking it as an adjectival modification of 'Christ's afflictions' can be countered by recalling that where two or more attributives follow a substantive the article is frequently omitted. 4

This observation in itself rules out the popular understanding of the afflictions of Christ as the 'messianic birthpangs' because there is no sense in which such afflictions could be encompassed within Paul's personal experience. But there are other points at which the apocalyptic argument is weak. The definite article before 'afflictions' is adequately explained by the fact that Paul has in mind the totality of Christ's sufferings; this, not the period of apocalyptic afflictions, is the

130; A.T. Hanson, The Paradox of the Cross in the Thought of St Paul (Sheffield, JSOT Press 1987) 160; F.F. Bruce, The Epistles to the Colossians, to Philemon, and to the Ephesians (Grand Rapids, Eerdmans 1984) 81-2; J.B. Lightfoot (Saint Paul's Epistles to the Colossians and to Philemon (London,

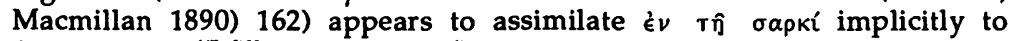

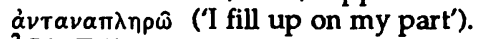

${ }^{3}$ Cf. T.K. Abbott, The Epistles of Paul to the Ephesians and to the Colossians (Edinburgh, T \& T Clark) 232: Abbott argues that the words are best connected with 'For if the writer had intended them to be taken with the verb, he would doubtless have written'.

${ }^{4}$ F. Blass, A. Debrunner, A Greek Grammar of the NT and Other Early Christian Literature (Chicago, University of Chicago Press 1961) \$269. Note also \$272: There are a number of examples of the omission of the article in the NT which are generally accepted, even apart from those cases where the substantive has other attributives'. 
'definite or well-known entity' indicated. ${ }^{5}$ The article before 'Christ' upon which E. Best, following Thornton, bases his eschatological interpretation, is not extraordinary (cf. $\delta$

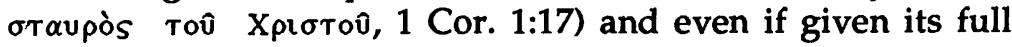
weight 'the afflictions of the messiah' need not carry any eschatological overtones. ${ }^{6}$ Best's appeal to the similar phrase

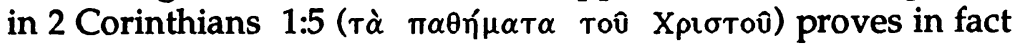
to be a liability since it is matched by the comfort that over-

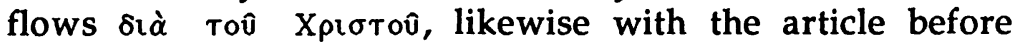
Xplotou: but there is no concept of 'messianic com-fort' alongside the messianic birth pangs. More decisively, it is very difficult to understand how Paul could claim to be enduring the messianic woes for the sake of the church. O'Brien writes:

By filling up what was lacking of a predetermined measure of afflictions which the righteous must endure, Paul also reduces the tribulations other believers, especially these Gentile Christians at Colossae, are to experience. The more of these sufferings he personally absorbed, as he went about preaching the gospel, the less would remain for his fellow Christians to endure. ${ }^{7}$

But several objections arise. First, there is no hint elsewhere in Colossians that he believed the world to have entered into the period of eschatological suffering. The exhortatory thrust of the letter is not the enduring of tribulation but the putting off of the old nature; the theological focus is on the past reconciliation rather than on future judgment. Secondly, the 'predetermined measure' of the messianic woes was temporal rather than quantitative. ${ }^{8}$ Thirdly, it is inconceivable that Paul should have supposed that his personal suffering would

${ }^{5}$ Cf. O'Brien, op. cit. 78. Note also the definite article in Rom.5:3: Not only that, but we also boast in the afflictions'.

${ }^{6}$ Best, op. cit. 130-6. Note H. Schlier, $\theta \lambda i \beta \omega, \kappa \tau \lambda ., ~ T D N T$ III 144-6. It is not obvious that (not a phrase found in the NT, though cf. Mk 13:8; Mt.24:8) and $\alpha \mathrm{i}$ $\theta \lambda \hat{i} \psi \in i S$ Tôे Xplotov̂ can be regarded as 'synonymous and equivalent' (O'Brien, op. cit. 79).

${ }^{7} \mathrm{O}^{\prime}$ Brien, op. cit. 80. Cf.Bruce, op. cit. 83; Best, op. cit. 136; R.J. Bauckham, 'Colossians 1:24 Again: The Apocalyptic Motif' EQ 471975.

${ }^{8}$ Note, e.g., Mk 13:20; cf. 2 Baruch 26-30 (J.H. Charlesworth, The OT Pseudepigrapha I (London, Darton, Longman \& Todd 1983) 630); and W. Michaelis $(\pi \alpha \sigma \alpha \omega, \kappa \tau \lambda ., T D N T V 933$ n. 20): 'The idea of a fore-ordained amount of suffering which has to be met is present neither in Paul. . . nor elsewhere in the NT, nor is it suggested by contemporary assumptions'. 
have made any significant difference to the universal tribulation of the end time. And, finally, the verb $\alpha \nu \tau \alpha \nu \alpha \pi \lambda \eta \rho \hat{\omega}$ means, fundamentally, 'to complete', not 'to contribute towards

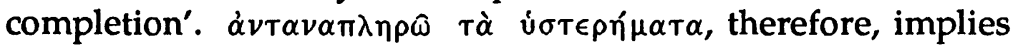
that he thought it possible to make up the whole deficiency, a prospect quite extravagant in the context of the messianic sufferings. The same argument also forestalls explanations of the verse that postulate the body of Christ as the appropriate interpretive context: ${ }^{9}$ Paul cannot mean that he expects to fill up in his own flesh the afflictions of the whole body.

The two u̇tè phrases in Colossians 1:24 need to be considered closely. It is sometimes suggested that, since Paul had not directly ministered to the Colossians, úmé $\dot{u} \mu \omega \hat{v} \nu$ should be attached to $\chi \alpha \hat{i} \rho \omega$ rather than to $\dot{\epsilon} \nu$ roîs $\pi \alpha \theta \dot{\eta} \mu \alpha \sigma \imath \nu \cdot$ it is the rejoicing that is for their sake, not the suffering. But how were the Colossians to benefit from his rejoicing? If Paul is happy on their behalf, it is precisely because they benefit from his suffering. I would suggest, therefore, particularly in the light of

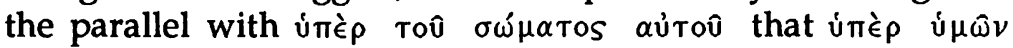
attaches to the sufferings and that either $\dot{u} \mu \hat{\omega} v$ must be understood in an extended sense- the Colossians as representative of the whole church, ${ }^{10}$ or that Paul's sufferings for the sake of the Colossians are to be explained in the light of 2:1: ' 1 want you to know what great conflict, $(\dot{\alpha} \gamma \hat{\omega} v \alpha), 1$ have for your sake, (u் $\pi \grave{\epsilon} \rho$ $\dot{u} \mu \omega \hat{v}{ }^{\prime}$ ). (Cf. 2 Cor. 11: 28: 'Apart from all other things there is my daily pre-occupation, the care for all the churches'.) Similarly, in the second part of the verse it is Paul's experience of the afflictions of Christ in his flesh that is $\dot{u} \pi \hat{\epsilon} \rho$ Toû $\sigma \omega \mu_{\alpha}$ Tos $\alpha \dot{v} \tau o \hat{u}$, not specifically and restrictedly the completion of the deficiency. The church benefits from the fact that Paul has suffered and continues to suffer, enduring what remains for him to be endured. In this case, we have a further reason for insisting that $\dot{\epsilon} \nu \tau \hat{\eta} \sigma \alpha \rho \kappa \mathcal{C}^{\prime} \mu \mathrm{OU}$ adheres closely to

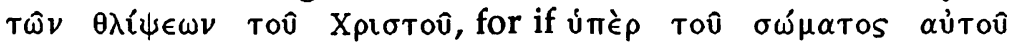
qualifies the afflictions of Christ, it is hardly possible to

\footnotetext{
${ }^{9} \mathrm{Eg}$. R. Yates, 'A Note on Colossians 1:24' EQ 42 (1970) 91; Bruce, op. cit. 81-4; Hanson, op. cit.164; Robinson, op. cit. 70-71; C.M. Proudfoot, 'Imitation or Realistic Participation?' Interpretation 17 (1963) 158; F.W. Beare, The Epistle to the Philippians (London, A \& C Black 1959) 123-4.

${ }^{10} \mathrm{Cf}$. O'Brien, op. cit. 76.
} 
detach the intervening phrase.

If the apocalyptic interpretation is rejected, what then is to be made of the idea that Paul completes the afflictions of Christ in his flesh? Numerous explanations have been put forward, many starting out from the assumption that Paul cannot have meant that Christ's afflictions were somehow deficient. ${ }^{11}$ There is little need to consider these in detail, particularly if it can be shown that Paul's words convey perfectly good sense at face value. J.B. Lightfoot argues that any attempt to ascribe a meaning to the genitive construction other than the obvious one forces the sense of the expression. The 'afflictions of Christ' are simply the afflictions 'which Christ endured'.12 The distinction which he then makes, however, between those afflictions which are satisfactoriae, having a 'sacrificial efficacy', and those which are aedificatoriae, spiritually and morally upbuilding, cannot-in this context at least-be sustained. It is certainly true that the expression would not have suggested a sacrificial act. ${ }^{13}$ But apart from the fact that it is only in the vaguest, exemplary sense that the afflictions of Christ can be said to contribute to the upbuilding of the church, we still have the problem that Paul appears to have thought it possible to make up the deficiency in his own flesh. Lightfoot's argument that the 'present tense denotes an inchoate, and not a complete act' is an attempt to get round this problem but it is not quite accurate. The present tense only indicates that Paul is in the process of filling up, of making good the deficiency. ${ }^{14}$ In the end, the distinction between sacrificial and edifying afflictions is irrelevant because it is not the afflictions in themselves that Paul claims are incomplete.

This much allows the suggestion that Paul regards the

\footnotetext{
${ }^{11} \mathrm{O}^{\prime}$ Brien, op. cit. 77-8; Hanson, op. cit. 160-3.

${ }^{12}$ Lightfoot, op. cit. 163.

${ }^{13}$ Best, op. cit. 132.

${ }^{14}$ Abbott makes a similar point (op. cit. 231), though without clearly grasping the fact that Lightfoot uses the word 'inchoate' in order to get round the implication that Paul expected to supply the complete deficiency himself.

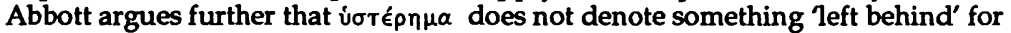
Paul to make up, as Lightfoot thinks, but 'a want of sufficiency'. This is correct, but I would stress that the want is not in the afflictions themselves but in the extent to which they have been matched in Paul's own experience.
} 
afflictions of Christ ${ }^{15}$ as the model or pattern for his own sufferings and that the deficiency in his flesh is the extent to which he has not yet suffered as Christ suffered. The limit to such suffering is death. The precise force of the prefix $\alpha \nu \tau t-$ in the verb $\alpha \nu \tau \alpha \nu \alpha \pi \lambda \eta \rho \hat{\omega}$ is difficult to calculate. ${ }^{16}$ According to the present interpretation Paul's thought involves two transfers, both of them evident in the juxtaposition of 'in my flesh' and 'for the sake of his body'. The contrast between ' $m y$ flesh' and 'his body' points to the transfer of the pattern of suffering from Christ to Paul; that between Paul's own person (his flesh) and the church points to the transfer of the benefits of his suffering. Either of these shifts could account for the prefix, though since the action of the verb defines the transfer of sufferings from Christ to Paul, the former is more likely. Arguably, though, the addition of the prefix is as much stylistic as semantic or logical, giving an emphasis to the verb appropriate to the confession of such a radical ambition.

T.K. Abbott comes close to this interpretation when he accounts for Paul's description of his troubles as the afflictions of Christ in his flesh by saying that 'Christ's afflictions are regarded as the type of all those that are endured by His followers on behalf of the Church'. ${ }^{17}$ This is essentially correct, but two important emphases are missing. Firstly, the afflictions of Christ must be understood in a fairly precise sense as afflictions culminating in and limited by death, otherwise it is not possi-

\footnotetext{
${ }^{15}$ It is commonly asserted that nowhere else in the NT is $\theta \lambda$ í 2 s applied to the sufferings of Christ (Lightfoot, op. cit. 164; Bruce, op. cit. 83 n.208). But this need only reflect the fact that the sufferings have been transferred from Christ

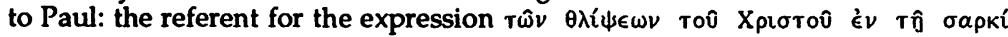
rou is in fact Paul's sufferings, not Christ's. There is a similar indirect allusion

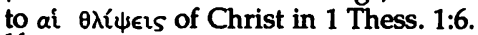

${ }^{16}$ Lightfoot, op. cit. 162-3: 'It signifies that the supply comes from an opposite quarter to the deficiency'; Abbott, op. cit. 229-30: àvr 'indicates the correspondence with the vi $\sigma \tau \tau_{\rho} \eta \mu \alpha^{\prime}$ (cf. Bruce, op. cit. 81-2 n. 204; O'Brien, op. cit. 80); Robinson, op. cit.70: Paul fills up 'in their stead' the suffering that the

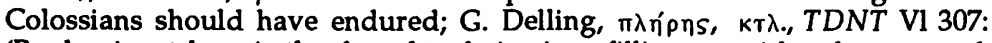
'Predominant here is the thought of vicarious filling up with reference to the measure of eschatological affliction laid on the community in the non-mystical but soberly realistic fellowship of its destiny with Christ'; C.F.D. Moule, An Idiom-Book of NT Greek (Cambridge, CUP, 1953) 71: 'the àvTL - may merely imply that fulness replaces lack, or may anticipate the force of the úmè which follows'.
}

${ }^{17}$ Abbott, op. cit. 232. 
ble to give proper weight to the idea of making up the deficiency: this, in fact, is the criticism that $O^{\prime}$ Brien makes. ${ }^{18}$ It is in this sense that Christ's sufferings constitute a pattern. Secondly, the afflictions of Christ are a type not merely incidentally. Paul has deliberately chosen them as the model for his own sufferings and it is his intention or expectation to experience their full scope. There is, moreover, in this context an intensely personal aspect to Paul's words which is not adequately encompassed by the broad typological designation of the suffering of all Christians as the afflictions of Christ. Paul is speaking here emphatically and autobiographically about himself and his apostolic role, as the rest of the chapter makes clear, and not about all Christians. This is a consideration that will acquire greater significance when we look at our second passage.

\section{Philippians 3:10-11}

The statement about the connection between Paul's sufferings and those of Christ in Colossians 1:24 precedes an account of his apostolic ministry and of his anxiousness for the spiritual well-being of the Gentile churches. In Philippians 3:10-11 a similar statement appears in the context of an extensive and more profoundly personal account of his former life under Judaism, the total reversal of values that accompanied his conversion, and the hope and ambition that motivate his Christian life: Paul has counted all that was once gain as loss 'in order to know him and the power of his resurrection and participation in his sufferings, being conformed to his death if somehow I might come to the resurrection from the dead'.

This translation, which follows the syntax of the Greek as closely as possible, is not especially controversial. But two significant interpretative difficulties should be noted. First, what is the nature of the 'participation' in the sufferings

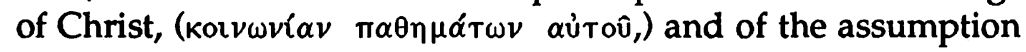

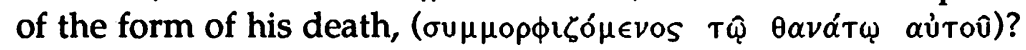
Secondly, what is to be made of the apparent element of uncertainty in Paul's expectation of coming to the resurrection from the dead?

As with Colossians 1:24 the clue to what I would argue

${ }^{18}$ Ơ Brien, op. cit.78. 
is the most satisfactory interpretation emerges from the structure of the sentence. W. Michaelis has suggested that a chiasmus underlies these verses, one which points to an identifica-

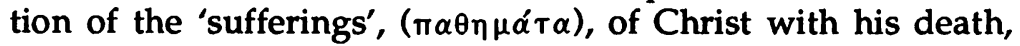
though he admits that Paul never uses the verb $\pi a \theta \in \hat{\imath} v$ to denote Christ's death: ${ }^{19}$
A the power of his resurrection
B participation in his sufferings
$B^{\prime}$ being conformed to his death
$A^{\prime}$ the resurrection from the dead.

There is a superficial impressiveness about such an arrangement -Michaelis does not set it out in this way-but there are also difficulties with it. Some of these will emerge later when we consider the place of these verses in the whole passage, but for the moment we need simply note that, even if Paul was consciously aiming at an inversion of vocabulary or ideas, this is not a sufficient argument for equating the sufferings with the death alone. Such an assumption would make sense only if, as G.F. Hawthorne argues, Paul's involvement with the sufferings and death of Christ is to be interpreted according to the terms of a passage such as Romans 6:4-11. ${ }^{20}$ Then the death of Christ would be that which is appropriated by the believer at baptism and it would be possible to speak of 'participation' (kou $\nu \omega \nu^{\prime} \alpha$ ) in it. But if we take this line, certain discrepancies trip us up, for Paul argues in Romans 6:5 that if we have become united in the likeness of his death, then certainly we shall also be (in the likeness) of his resurrection'. Here 'the likeness of his death' is a reference to baptism, 'we were buried therefore with him by this baptism into death', verse 4 , and belongs to the past; there is no mention of sufferings and the prospect of resurrection for all believers because of this death is not in doubt (cf. verses 8-9). In Philippians 3:10-11, by contrast, the involvement in suffering is a present experience that stretches into the future; and the prospect of resurrection is marked by an uncertainty which cannot be explained away as 'humility and

${ }^{19}$ Michaelis, TDNT V 932; cf. G.F. Hawthorne, Philippians (Waco, Word Books 1983) 145.

${ }^{20}$ Hawthorne, op. cit. 144; cf. C.F.D. Moule, The Origin of Christology (Cambridge, CUP 1977) 81, 124; Proudfoot, op. cit. 150-2. 
self-distrust' ${ }^{21}$ Paul's general, theological argument in Romans is very different to the personal statement that we find here in Philippians.

More important than what would be at best a redundant chiastic structure is the sense of progression underlying what Paul says here about suffering culminating in the hope of resurrection. The words 'if somehow I might come to the resurrection from the dead' constitute not a pious aside but the express upshot of the suffering and especially of the process of being conformed to Christ's death. They are rendered intelligible if we recognise that the alternative envisaged by Paul is not spiritual failure but that the parousia might take place before he dies, robbing him of the opportunity to complete, in the words of Colossians 1:24, what is lacking of the afflictions of Christ in his flesh. This is the crucial point in the argument: that, whereas v.10 speaks of an inwardly directed process, verse 11 and, as we shall see, the ensuing verses speak of the temporal frame of that process. The element of motion in the verb that Paul uses here, ( $\kappa \alpha \tau \alpha \nu \tau \eta \dot{\sigma} \sigma \mathrm{eis}$ ), has now become significant: the thought is that he might continue until resurrection. Resurrection is uncertain for the simple reason that death itself is uncertain: if this were not so, we would be forced to say that Paul believed it possible to be conformed to Christ's death without the assurance of resurrection. If it is objected that according to Philippians 3:20-21 Paul still at this time eagerly awaited the return of Christ from heaven, let us simply note, on the one hand, that he now speaks not of himself alone but of the believers collectively, 'we await', and on the other, that his focus has shifted from the purely temporal issue to the contrast between the earthly hedonism of 'the enemies of the cross of Christ' and the prospect of bodily transformation both for those still alive and those in their graves at the return of Christ. The saviour is eagerly awaited not because he will preempt death but because he will transform the bodies of humil-

${ }^{21} \mathrm{M}$.R. Vincent The Epistles to the Philippians and to Philemon (Edinburgh, $\mathrm{T}$ \& T Clark) 106; cf. Hawthorne, op. cit. 146. Martin argues that Paul's uncertainty lies in regard to the manner in which he will come to resurrection, 'whether by martyrdom or at a more distant time, as in 1:20-6' (R.P. Martin,

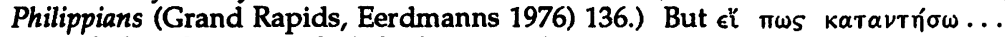
can only be taken to imply 'whether or not'. 
ity of the living and the dead (cf. 1 Cor. 15:42-44).

This insight-that it is for Paul the uncertainty of death that makes resurrection uncertain-allows us to give a more exact interpretation at two other points. First, the contrast with the possibility of being alive at the parousia is underlined by

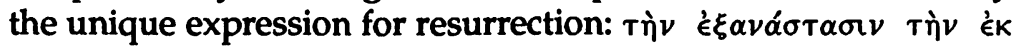
$v \in \kappa \rho \hat{\omega} v$. Hawthorne's argument that the contrast marked by the novel prefix $\dot{\epsilon} \xi$ - is between the literal resurrection from the dead and the mystical rising with Christ which is the present experience of all believers is mistaken. ${ }^{22}$ Paul never speaks of the present resurrection as being 'from the dead' (see Rom. 6:4-9; Col. 2:12; 3:1; Eph. 2:6); Hawthorne's interpretation, therefore, explains at most the qualification $\tau \grave{\eta} v$ ék $v \in \kappa \rho \hat{\omega} v$, not the prefix. Rather, the repeated preposition gives emphasis to the link between resurrection and death: it is a resurrection from the dead, in contrast to the assumption of the living at the parousia. Secondly, the present participle $\sigma u \mu \mu \circ \rho \phi i \zeta o$ ó $\mu \in \nu \circ S$ suggests a process in time which can be understood as congruent with the 'filling up' of Colossians 1:24. It is not the sort of sudden transformation that Paul describes in Philippians 3:21 ('who will transform our body of humility to be like, ( $\sigma u \mu_{\mu} \circ \phi \circ \nu$ ), his body of glory') but the continuous approach through suffering to the completion of the pattern, the form or $\mu \circ \rho \phi \eta^{\prime}$ in death.

The context of interpretation now needs to be extended by considering the place of these verses in Paul's immediate discussion. Much depends on the argumentative and rhetorical structure of the passage and for this reason the following translation of 3:7-14 is set out in such a way as to indicate the main structural relationships:

I

II

III

IV

$\mathrm{V}$

VI

(7) But whatever was to me gain, these things I have considered because of Christ loss.

(8) Indeed I consider all things to be loss because of the surpassing worth of the knowledge of Christ Jesus my Lord, for whose sake I have suffered the loss of all things, and consider them refuse

${ }^{22}$ Hawthorne, op. cit. 146-7. 
VIII in order that I may gain Christ (9) and be found in him, IX not having a righteousness of my own from the law but one through faith in Christ, the righteousness from God based on faith

$X \quad(10)$ to know him and the power of his resurrection and participation in his sufferings,

XI being conformed to his death (11) if somehow I might come to the resurrection from the dead.

XII (12) It is not the case that I have now obtained or have now reached the goal,

XIII but I press on if indeed I might take possession because I have also been taken possession of by Christ Jesus.

XIV (13) Brethren, I do not yet think that I have taken possession; $\mathrm{XV}$ but one thing, forgetting what lies behind but stretching out towards what lies ahead, (14) towards the mark I press on to the prize of the upward call of God in Christ Jesus.

The chiastic arrangement of verses 7-8 does not affect my argument directly but it does lend weight to the view that the passage is carefully structured. The main argument against the chiasmus is that, if it is disregarded, these verses look oddly repetitive and prolix. They consist of four statements (ll. I and II, III and IV, V and VI, VII and VIII), each of which, without great variation of expression, makes essentially the same point: the discounting of former gain for the sake of Christ. But the chiasmus is attractive. Working out from the centre: line $\mathrm{V}$ is an abridgement of line IV, both using the same preposition

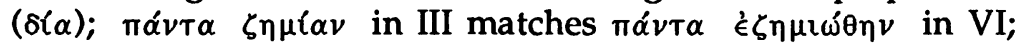
the verb iryéral occurs in both II and VII; and the verb

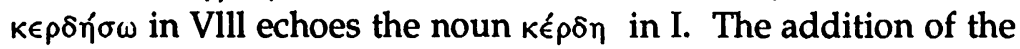
clause 'and be found in him' is characteristic of Paul's-style. ${ }^{23}$ More remarkable still, the word 'refuse' $\sigma \kappa u ́ \beta \alpha \lambda \alpha$ in line VII is the more forceful for suddenly displacing the word 'loss' (either as noun or verb), which has occurred in each of the three preceding statements; and the word 'gain' in line VIII has dramatically and pointedly changed its reference: not that which was gain in his former life $(l$. I) but the gain which is Christ. Finally, we might note that each half of the chiasmus (I-IV and V-VIII) is itself chiastic: gain-loss-loss-gain/gain-lossloss-gain.

${ }^{23} \mathrm{Cf}$. Blass' remarks on Paul's use of parallelism: op. cit. $\$ 490$. 
The participial clause at line IX is best regarded as a parenthetic qualification of the purpose expressed in line VIII. Line $X$ then stands as a statement of purpose either parallel to line VIII or dependent upon it. Given the change to a weaker construction-the articular infinitive, tov $\gamma \nu \hat{\omega} v \alpha$, rather than the iva clause-the latter is perhaps more likely. If this is the case, then the second statement of purpose can be understood as the more specific one, dependent on the prior acquisition of Christ-an arrangement which ties in neatly with my argument that in verses 10-11 Paul is speaking not of the inward dying and rising with Christ which is the experience of every believer but of his own radical personal commitment to suffer, if he is allowed to do so, to the full extent of the pattern of Christ's sufferings. ${ }^{24}$ By noting the relationship between lines VIII and $X$ we also draw attention to the fact that both purpose clauses are followed by present participles, an observation which goes someway further towards invalidating the claim that a significant chiasmus underlies verses $10-11$, since it suggests that the relationship between lines $X$ and $X I$ is primarily one of subordination rather than inversion. ${ }^{25}$

The parallelism that informs verses $12-14$ is relatively clear: lines XII and XIV are both denials of attainment; lines XIII and XV are statements of intention, both linked to the preceding disclaimers by $\delta \grave{\epsilon}$ and with $\delta \iota \omega \kappa \omega$ as the main verb, both ending with the name 'Christ Jesus'. This will prove to be of some help for our interpretation, but the more difficult problem lies in relating verses $12-14$ to what has gone before. ${ }^{26}$

\footnotetext{
${ }^{24}$ Note Beare's argument that the aorist of the articular infinitive (Tov $\gamma \nu \omega \hat{v a l}$ ) indicates an eschatological orientation (op. cit.122-3), which would suggest that even in v.10 Paul has in mind his own death and resurrection and not the more subjective, progressive experience of suffering and the compensatory 'power of Christ's resurrection'. In contrast, Proudfoot argues that both aspects are present in vv.10-11 (op. cit. 151): 'first, the resurrection power that even now is flowing into the life of the believer, and, in the last clause, the resurrection from the dead'. Cf. Hanson, op. cit. 82: Paul 'links knowing Christ with experiencing the power of his resurrection and sharing the fellowship of his sufferings, obviously a contemporary process. The goal of the process was his own resurrection from the dead'.

${ }^{25}$ This need not dispense with the chiasmus altogether, for there is no reason why different rhetorical structures should not overlap; when this is the case, however, it is important to decide which structure has logical priority.

${ }^{26} \mathrm{Cf}$. Hawthorne, op. cit. 149: 'One can only hope. . . to make an intelligent guess
} 
Specifically, what is it that Paul disclaims when he says in v.12 that he has not now 'grasped' or 'obtained', with the verb Ł̇ $\lambda \alpha \beta o \nu$ absolute, or 'been made perfect', $(\tau \in \tau \in \lambda \in i \omega \mu \alpha)$ ?

The solution which I will put forward rests on a number of important exegetical assumptions. These need to be elaborated. First, a similar uncertainty to that found in v. 11.. ( $\in l$ $\pi \omega s \quad \kappa \alpha \tau \alpha \nu \tau \eta \sigma \omega)$ is expressed in $v .12$ in the expression $\delta i \omega \kappa \omega \in i$ $\kappa \alpha \tau \alpha \lambda \alpha \beta \omega$ ('T press on to see whether/in the hope that I might take possession $\left.{ }^{\prime}{ }^{27}\right)$, which points towards the view that lines XIII and XV, which we have seen to be parallel, speak of the same ambition as line XI, the desire-or at least the willingness-to experience resurrection. This already suggests that line XII should be understood as a denial that he has achieved the purposes expressed in line XI. Secondly, the où öt which introduces line XII cannot be given the corrective sense that normally belongs to the English equivalent, Not that', at the beginning of a sentence. Paul's denial that he has already obtained or has already been made perfect is not intended to guard against a possible misinterpretation of what he has just said but simply reiterates the element of expectation in v.11; où $\chi$ ö $\pi$, therefore, should be translated less idiomatically 'It is not the case that'. This also accounts for the use of $\delta \dot{\epsilon}$ at the beginning of line XIII rather than the more strongly adversative $\dot{\alpha} \lambda \lambda \dot{\alpha}$ which follows the expression at 2 Corinthians 1:24, 3:5, and 2 Thessalonians 3:9. Thirdly, a significant step towards the correct reading will be made if it is recognized that $\eta$ ' $\delta$, which occurs twice in line XII, might be translated as 'now' rather than as 'already', so that the disclaimers refer to the present, not to the past as most interpretations suppose. ${ }^{28} \mathrm{~A}$ comparison with 2 Timothy $4: 6$ at this point, if it is allowed, is particularly illuminating: 'For I am now ( $\eta \hat{\gamma} \delta)$ being sacrificed, and the time of my departure is at hand'. Paul's assertion in Philippians 3:12 is precisely that he is not now being sacrificed: the time of his departure is not yet at hand.

If it is correct to regard line XI as an expression of Paul's hope that he will, so to speak, live until his death and thus

as to how vv.12-16 fit with vv.4-11'.

${ }^{27}$ For the construction with $\epsilon i$ see Arndt, s.v. V 2.b; Blass, op. cit. $§ 368,375$.

${ }^{28}$ See Arndt, s.o. Also Hawthorne, op. cit.151. 
experience resurrection, then it now seems plausible to argue that line XII is simply a denial that he has now (he has in mind his present imprisonment) come to that point, that he faces imminent death-though humanly speaking that was a real possibility. The verse is simply a reaffirmation of what he has already told the Philippians (1:24-6), that he expects to remain in the flesh some time longer; his imprisonment should not, therefore, be a cause for alarm (cf. 1:12-14). ${ }^{29}$

The implied object, therefore, of the absolute $\epsilon^{\prime} \lambda \alpha \beta o \nu$ is the desire expressed in the preceding line: 'It is not the case that I have now got what I want'. The fact that the verb is absolute, however, means that the accent falls heavily upon the unfulfilled status of the action. ${ }^{30}$ The same is true in line XIII, where $\kappa \alpha \tau \alpha \lambda \alpha \beta \omega$ is also absolute. What Paul is concerned with primarily in lines XII and XIII is not the object of his ambition but the incompleteness of his present position and the need to 'press on'. The precise meaning of the second verb is more difficult to pin down; but in the light of what has been established so far it seems likely that it refers to the fulfilment of his ambition. A rather exact antecedent for $\tau \in \tau \in \lambda \in i \omega \mu \alpha$, and also for $\ddot{\epsilon} \lambda \alpha \beta \circ \nu$, can be elicited if we recognize a chiastic relationship between lines XI and XII:

A ... being conformed to his death

B if somehow I might come to the resurrection from the dead.

$B^{\prime}$ It is not the case that I have now obtained

$\mathrm{A}^{\prime}$ or have now been made perfect...

In this way the perfection he has in mind is the completion of the process of conformation to the sufferings and ultimately the death of Christ. The tense of the verb, however, might be thought to militate against such an equation, in which case a safer course would be to translate the second disclaimer more broadly thus: 'It is not the case that. . . I have now reached the goal, i.e. the moment of death', carrying over the idea of 'coming to' the resurrection from the dead expressed in

\footnotetext{
${ }^{29}$ The link with 1:24-6 must have some bearing on the question of the unity of the epistle.

${ }^{30}$ Note V.C. Pfitzner, Paul and the Agon Motif (Leiden, Suppl. to Novum Testamentum 16, 1967) 144.
} 
$\kappa \alpha \tau \alpha \nu \tau \eta ́ \sigma \omega$ in v.11. ${ }^{31}$ Yet while the precise connotations perhaps remain elusive, it is clear that we can now establish a fully satisfactory, concrete interpretation of the verse, the proper context for which is neither the rather vague exhortation to moral or spiritual perfection that is sometimes invoked, ${ }^{32}$ nor any polemic against gnostics and perfectionists, ${ }^{33}$ but simple a statement of Paul's intention.

This seems enough to establish that lines XII-XV should be interpreted quite specifically in the light of lines $X$ and XI. Two further exegetical implications might then be noted. The first concerns the reciprocal use of $\kappa \alpha \tau \alpha \lambda \alpha \mu \beta \alpha \dot{\alpha} \omega$ in line XIII: 'but

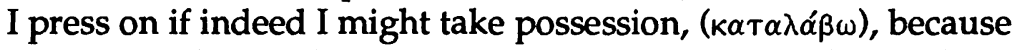
I also have been taken possession of, $(\kappa \alpha \tau \in \lambda \eta \mu \phi \phi \theta \eta \nu)$, by Christ Jesus'. The object of $\kappa \alpha \tau \alpha \lambda \alpha \beta \omega$ is clearly that which Paul denies having yet obtained in line XII. The change in vocabulary represents a shift towards the race metaphor that emerges more fully in line XV; $\kappa \alpha \tau \alpha \lambda \alpha \mu \beta \alpha ́ v \omega$ is a natural sequel to $\delta \omega \omega \kappa \omega$ (cf. Sir. 11:10; 27:8). The sense of the verb when used reciprocally cannot be quite the same, ${ }^{34}$ and the repetition must be considered primarily stylistic. The underlying thought is unchanged: the dynamic framework for his continuing apostolic work is set by this hope of coming to the resurrection from the dead.

The second point concerns the meaning of the phrase 'the prize of the upward call of God in Christ Jesus' in verse 14. Again most interpretations assume that the 'upward call' is general, applicable to all believers, 'upward' in the sense that God calls people into his presence or into his kingdom; but my argument so far has been that Paul's stated ambition in this passage is a specific, personal one. Since line $\mathrm{XV}$ is parallel to line XIII and through that parallelism linked to line XI, it seems reasonable to expect the same specific idea here. To give further support to this it should be noted that if the 'call' is the

\footnotetext{
${ }^{31}$ Cf. Lk 13:32; see Arndt, s.v. 1.

${ }^{32} \mathrm{Eg}$. Vincent, op. cit. 107. Only at v.15 does Paul generalize, shifting from a statement of his own peculiar hopes to paraenesis.

${ }^{33}$ Eg. Martin, op. cit. 134, 136ff; Beare, op. cit. 129-30; Pfitzner, op. cit. 144ff; Hawthorne, op. cit. 150ff. The emphatic use of $\dot{\epsilon} \gamma \omega$ and $\dot{\epsilon} \mu a v$ tò in v.13 is not polemical: Paul's purpose is rather to allay Philippian alarm at his imprisonment, a concern on his part which is also evident in 1:12-14.

${ }^{34}$ In Mk 9:18 the word is used of a demon seizing a sick man; given the evident rhetorical play in this verse, such a nuance would not be out of place.
} 
general one, then it should be in the past rather than in the fu-

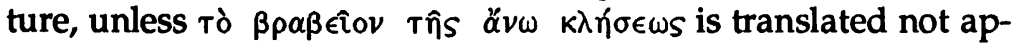
positionally but as 'the prize which results from the upward call'. Such a use of the genitive, however, is strained and the appositional sense, 'the prize which is the upward call', is far more likely. Hawthorne, rejecting the appositional interpretation, pursues instead Collange's argument that Paul is alluding here to the call of the agonothete to victorious athletes to come up and receive the prize of a palm branch. ${ }^{35}$ But again the genitive hardly allows for the sense the prize which is given at the upward call'. The analysis of the passage to this point suggests an interpretation which accords neatly with the most natural meaning of the genitive construction: it is that the 'prize of the upward call of God in Christ Jesus' is the prize of the call to resurrection, ( $\alpha \nu \alpha \sigma \tau \alpha \sigma i s)$, from the dead. This is the significance of the adverb ă $v \omega$ : it is literally a call upwards, a call to arise (cf. 1 Thes. 4:16: 'the Lord himself will descend from heaven with a cry of command, with the voice of an archangel and with the sound of the trumpet of God. And the dead in Christ will rise $\alpha v \alpha \sigma \tau \eta^{\prime} \sigma o v \tau \alpha$ (first'). ${ }^{36}$ And the element of uncertainty that we have traced from verse 11 appears again in the image of the prize: it is not a foregone conclusion that an athlete will attain the prize, it is not certain that Paul will experience the resurrection from the dead.

\section{Conclusions}

The argument of the preceding analyses has been that when Paul speaks personally about participating in or making up what is lacking in the sufferings of Christ, there is at the root of his thinking a commitment to suffer on behalf of the church to the extent that Christ suffered (without, of course, any idea of atoning value); and that what he saw as the main obstacle to achieving this aim was the possibility that Christ would return before he died. What these two passages reveal

\footnotetext{
${ }^{35}$ Hawthorne, op. cit.154-5.

${ }^{36}$ An interesting parallel is found in the Greek Apocalypse of Baruch 4:15

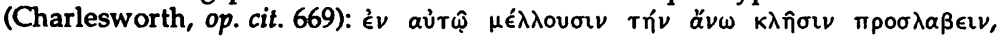

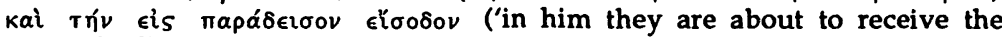
upward call and the entrance into paradise'). The future tense suggests that $\tau$ r $v$ $a \ddot{v} \omega \kappa \lambda \hat{\sigma} \sigma \nu$ is an allusion to the resurrection.
} 
is an involvement in the sufferings and death of Christ that is objective rather than subjective, but which is essentially imitative $^{37}$ and must be interpreted chiefly in the context of Paul's apostolic self-understanding. Any views that he may have had about the somatic or mystical participation of the believer in the reality of Christ have no significant bearing on the meaning of these passages; nor does the concept of a period of eschatological suffering play any part in his thought.

It is also the profoundly personal dimension that marks these two passages off from others that describe the fellowship of believers in suffering or their participation in the death of Christ. ${ }^{38}$ The ideas, of course, are related but the intention is very different. The passage that perhaps comes closest, and which is usually cited in this context, is 2 Corinthians $1: 4-7$ (note also 2 Cor.4:8-12; Rom. 8:17), but here it is to Paul and Timothy together that 'the sufferings of Christ abound', and the emphasis is simply on the benefit to the church of the comfort that abounds through Christ as a result of the apostles' afflictions: I would dispute Proudfoot's claim that Philippians 3:10-11 forms basically the same proposition as 2 Corinthians $1: 5$ ' and that consequently 'the power of Christ's resurrection' in Philippians 3:10 is to be identified with the 'comfort' that comes from Christ. ${ }^{39}$ Finally, it might be appropriate to find hints of these ideas in 1 Thessalonians 1:6, which carries the implication that Paul in his affliction is an imitator of the Lord, and in 2 Corinthians 4:10, where the 'dying/putting to death' ( $\nu \in \kappa \rho \omega \sigma \iota v)$ of Jesus suggests a process of suffering patterned on Christ that will ultimately culminate in death.

Certain broader implications can also be drawn, parenthetically, from this study. It seems fair to say that the persistent comparative method of NT exegesis must take much of the blame for the confusion that has been generated by attempts to resolve the seeming anomalies of these two brief passages. As we have seen, it is a mistake to think that the language of suffering with Christ and participation in his death always

\footnotetext{
${ }^{37}$ Against Proudfoot, op. cit.'

${ }^{38} \mathrm{Cf}$. Michaelis, TDNT V 932; Pfitzner, op. cit. 139: Pfitzner correctly stresses the primarily autobiographical aspect of Phil.3:12-14 over against the paraenetic but is wrong to couple it with an apologetic purpose.

${ }^{39}$ Proudfoot, op. cit.151.
} 
presupposes the same context of thought. The comparative method inevitably inclines towards generalizations.

Our findings have bearing on the discussion of how Paul thought of his own death and eschatology. He considered his sufferings to be defined by Christ's sufferings. They brought benefit to the church because, on the one hand, they were a product of his apostolic ministry and concern, and on the other, because from affliction sprang comfort in Christ (2 Cor.1:4-7). He looked upon the possibility of dying not as a martyrdom, ${ }^{40}$ as death for its own sake, but as a fulfilment of the pattern of Christ's suffering and, especially if we allow the implications of our interpretation of Philippians 3:11 to run through to verse 14 , as the means to attain the prize of resurrection. It is not death rather than life that Paul sought for himself, which is martyrdom, but death (on the assumption that his activities would sooner or later result in his execution) rather than 'rapture'. This gives a slightly different emphasis to what we find in 1:21-4, where it is the prospect of being with Christ that makes death preferable to life. But here Paul is talking about his present state of mind: given the choice he would rather die now. Having accepted that he must continue in the flesh, his point in 3:10-11 is that he would rather continue until death than be alive at the parousia. It is difficult to tell which he thought most likely. The emphasis on pressing on and reaching out towards the goal of resurrection has suggested that to fulfil the pattern of Christ's sufferings was a conscious ambition for Paul. But the line between desire and expectation can be fine, and it may well be that Philippians 3:11-14 is more a statement of expectation, of what Paul thought would happen, than of desire. This does not weaken the claim that he considered Christ's sufferings unto death to be the pattern of his own, and he either believed or hoped that such would be the outcome.

\footnotetext{
${ }^{40} \mathrm{It}$ is Lohmeyer's thesis that in this passage Paul is speaking of martyrdom (discussed in Hanson, op. cit. 81; Pfitzner, op. cit. 146-7). Hanson argues that Paul is too much concentrated on his relationship to Christ in the course of his apostolic ministry to concern himself with whether in fact it matters that ultimately he should be put to death for Christ's sake'. This is rather idealistic: it is correct in that Paul did not seek martyrdom, but his consciousness of experiencing the sufferings of Christ was much stronger than such an account allows.
} 